\title{
THE INCEPTION: A INDISSOCIABILIDADE E A SIGNIFICÂNCIA DOS TERRITÓRIOS MATERIAL E IMATERIAL
}

\author{
Tiago Egídio Avanço Cubas \\ Mestrando em Geografia: FCT-UNESP (Presidente Prudente - Brasil) \\ Correio eletrônico: tiagotec_geo05@yahoo.com.br \\ Recibido: 30 de agosto de 2011. Aceptado: 14 de septiembre de 2011
}

\begin{abstract}
RESUMO
As disputas territoriais no mundo estão cada vez mais em evidencia. Essas disputas têm por base as relações sociais e as correlações de força que se desenham pelo espaço a nível global, regional e local. Esses conflitos se dão no embate de forças que se estabelecem tanto no plano físico e material, quanto no plano invisível e imaterial. A formação social da mente então está sujeita as ideologias dominantes (as visões de mundo que se territorializam nos símbolos e signos sociais) que se espacializam cotidianamente. E na contraposição a esses territórios temos a resistência e a (re)criação que legitima outros territórios que visam uma não subalternidade a visões de mundo dominadoras. Assim o território se forma a partir das relações sociais e de poder que estão implícitas e explícitas no material e no imaterial, desse modo configura-se a realidade.
\end{abstract}

Palavras-chave: Território, disputa territorial, ideologia, relações sociais, relações de poder.

\begin{abstract}
The territorial disputes in the world are increasingly in evidence. These disputes are based on social relations and the correlation of forces that are designed for space at the global, regional and local levels. These conflicts take place in the clash of forces that are established at both the physical and material, as the plane invisible and immaterial. The social formation of mind then is subject to dominant ideologies (the worldviews that territorialize social symbols and signs) that specializes daily. And in contrast to these territories have the resistance and (re)creation that legitimizes other territories aimed at one not subordinate to dominant worldviews. Once the territory is formed from the social and power relations that are implicit and explicit in material and immaterial, this way the reality is configured.
\end{abstract}

Key-words: Territory, territorial dispute, ideology, social relations, power relations. 


\section{RESUMEN}

Las disputas territoriales en el mundo están cada vez más en evidencia. Estas disputas están basados en las relaciones sociales y la correlación de fuerzas que están diseñados para el espacio en los planos mundial, regional y local. Estos conflictos tienen lugar en el choque de fuerzas que se establecen, tanto en lo físico y material, como el plano invisible y inmaterial. La formación social de la mente, entonces está sujeto a las ideologías dominantes (las visiones del mundo que territorializar símbolos sociales y signos) que se especializa cada día. $\mathrm{Y}$ en contraste con estos territorios tienen la resistencia y (re)creación que legitima otros territorios con objeto de no subordinarse a las visiones del mundo dominante. Así el territorio está formado por las relaciones sociales y de poder que están implícitos y explícitos en material e inmaterial, la realidad se configura de esta manera.

Palabras-clave: Territorio, disputas territoriales, ideología, relaciones sociales, relaciones de poder.

\section{INTRODUÇÃO}

A realidade da formação do território tem como parte fundamental as disputas territoriais, as que se realizam no plano físico e por isso se tornam materialidade, e as que acontecem no plano imaterial, são imaterialidade, e se tornam materialidade e materialização nas ações (nos processos). Pensamos então em construir esse artigo para consubstanciar a possibilidade do território material e imaterial a partir das relações sociais, da dominação e da resistência. A partir da exposição de elementos do território, conspícuo e invisível, temos então, base teórica para fazermos a analogia com o The Inception. Uma proposta cinematográfica que enfoca o universo dos sonhos (ideias) e a realidade contraposta nesse território imaterial materializada nas relações sociais e nas relações de poder. Seguimos com o trabalho na construção da ideia e da ideologia, como uma força vital e visão de mundo que movimenta os desejos (dinâmica de viver nas ações).

Vamos expor também o exemplo do Just do it (Nike) para entendermos como as relações sociais, a lógica do capital, e a lógica anticapitalista vislumbra os territórios na realidade, como se dispõem a sua essência e aparência. A partir disso pensaremos o território e a ideologia como distintos. Esses conceitos nos auxiliarão a entender a questão agrária de maneira geral e mais especificamente a paulista quando pensaremos os paradigmas como interpretação da realidade e visão de mundo.

\section{RELAÇÕES SOCIAIS E DE PODER, O TERRITÓRIUM COMO ESPAÇO DE VIDA}

\section{Ratzel e Raffestin: o território e o poder}

Os conflitos e as disputas no e pelo poder (poder de fazer, de dizer, de estar, de realizar) que co-determinam as relações sociais, nas escalas micro a global, nas várias dimensões da atuação humana, fazem imprescindíveis as investigações científicas para entender os seus desdobramentos em mazelas, alianças, coerções, conflitos, entre outros elementos que então compõem o espaço e as suas temporalidades. Como resultado das relações 
humanas que envolvem poder no espaço, o território então se tornou a partir da década de 1980 e o início do século XXI um conceito fundamental para a ciência geográfica.

Esse conceito foi trabalhado desde a ciência filosófica, por Deleuze e Guattari (1972) e chegou a geografia abordado por Ratzel (1990), historicamente no Estado alemão, e após isso por Jean Gottman (1973), Claude Raffestin (1993), Rogério Haesbaert (2004a e 2004b), Bernardo Fernandes (2008b e 2009) entre outros. Foi destacado nessas abordagens pelas suas características, etimologia, elementos que o compõem e auxiliam na investigação e entendimento da realidade. As relações sociais mediadas então pelas relações de poder e consubstanciada nas correlações de força no espaço formam o território, como o vemos, o território conspícuo, e o que não vemos, o território invisível, mas que se materializa de formas distintas.

Assim o território é gerado nas relações. Ele está cercado de caracterizações, mas em nossa leitura o conteúdo para explicação da realidade (potencialidade) desse conceito está nas ações da des-re-territorialização que pertencem a materialidade e a imaterialidade (Deleuze e Guattari, 1972). O que se desdobra no plano físico é também a constatação relacionada a super-estrutura é o que está fora da visão do olho humano, mas que pertence a expressão territorial. Eles se traduzem no motivo, na razão filosófica, os elementos histórico-geográficos que co-determinam as relações sociais e o poder.

A priori, examinando os dicionários de latim e francês para definir etimologicamente o termo território: vemos que ele é formado pelo radical em latim, territórium (terra, pedaço de chão, utilizado no império romano para delimitar suas jurisdições). Pensando em jurisdições, como toda terra debaixo da proteção ou domínio de Roma podemos entender também perceber as vertentes material e imaterial do território no processo de dominação (imposição), dominados e resistentes, e ainda da construção do poder vindo horizontalmente pela expansão desse território (nas correlações de força) e verticalmente pelo Estado romano (Haesbaert, 2004b). Essa definição é falha quando nos preocupamos em resolver o conceito de território, mas reflete a importância de perceber o território como material e imaterial, simbólico e indissociável, ele reflete muito mais que sua etimologia, ela contém nele as relações sociais como codeterminante da sua história e geografia.

Inspirando-se na visão etimológica do território, a formação desse conceito passa pelos seus sentidos funcionais e simbólicos. Entendemos que o mesmo é o conceito possível para interpretarmos a realidade composta por elementos naturais, políticos, econômicos, sociais e culturais. E através disso, a sobreposição de territórios nas suas diversas facetas e constituições, a multiterritorialidade aparece para contemplar a necessidade de se explicar a complexidade das relações espaço-sociedade-temporalidade (HAESBAERT, 2004a). E vista também da etimologia da palavra, é essencial notarmos que o funcional e o simbólico consubstanciam o material, a materialidade e a materialização, mas também, pelo seu contrário (o dialético), o imaterial, a imaterialidade e a materialização, é claro, numa perspectiva integradora desses elementos.

Assim também devemos expor que o território é indissociável ao espaço, contudo, são elementos distintos. O espaço geográfico, alvo da geografia, é o todo e a razão geográfica $^{1}$, a categoria de análise que engloba o território. Assim concebemos o 
território como a parte do espaço dotada de relações sociais mediadas pelo poder nos seus sentidos mais amplos nas obras de Foucault (1979 e 1988) e Raffestin (1999).

Nosso ponto de partida são os trabalhos do alemão Ratzel (Antropogeografia) que vai expor o território como um conceito para se entender as relações humanas, nesse caso com vistas a formação do Estado-Nação, ele nos traz importantes contribuições, fundamentais para a formação dos pensadores do conceito de território.

Raffestin (1993) considera Frederich Ratzel como o pai da Geografia Política que é a gênese no pensamento do território, além de atrelar esse conceito ao homem, vida do homem e a natureza. Ratzel (1990), um naturalista, vai conceber e desenvolver a ideia de território vindo da biologia no conceito de habitat. "Pode-se, portanto aceitar com a regra que uma grande parte dos progressos da civilização são obtidos mediante um desfrute mais perspicaz das condições naturais, e que neste sentido esses progressos estabelecem uma relação mais estreita entre povo e território" (Ratzel, 1990, p. 72) e ainda complementa dizendo que "a sociedade que consideramos, seja grande ou pequena, desejará sempre manter sobretudo a posse do território sobre o qual e graças ao qual ela vive. Quando esta sociedade se organiza com esse objetivo ela se transforma em Estado". (Ratzel, 1990, p. 76). Era para ele o espaço vital como um território em excelência para reprodução da sociedade e aí já observamos a construção do conceito $a$ priori da dinâmica social. Ao contrário disso, sobre a noção da formação do território, Haesbaert (2004a) e Fernandes (2008b) aponta que o território se forma juntamente com a sociedade, nas suas relações ele desenha e redesenha nas suas continuidades e descontinuidades.

Verificando ainda as contribuições de Ratzel (1990) podemos observar que o território pode ser entendido como imprescindível para alcançar objetivos políticos, a proposição das relações sociedade, terra e tempo numa dinâmica de realizar o território, e a partir disso o Estado-Nação. O que fica para trás é a compreensão do território simplesmente pelo território, onde Ratzel (1990) coloca em segundo plano a necessidade da ação humana imanente ao território (isso para que ele exista), ao contrário do que observamos enraizado no próprio território explicitado por Raffestin (1993). Raffestin (1993), Haesbaert (2004) e Fernandes (2008b e 2009) já reforçam em suas obras que análise do território Estado-Nação é por si só uma parcela da realidade e definitivamente não o todo, eles afirmam a existência, desde Raffestin (1993), do Poder (poder público, Estado: forma institucionalizada dos fluxos das correlações de força nas relações sociais) e do poder (correlações de força, e expressão concreta e abstrata das relações sociais que emanam de baixo para cima) no território que influi no processo des-re-territorialização (T-D-R).

No final do século XIX, Ratzel (1990) visava o elo entre a dimensão natural-físicapolítica, utilizava o conceito de território estatal, não por menos, pois vivia na época de unificação da Alemanha, então vemos também realidade vivida por ele influenciando na formação desse conceito. Mas não ficou somente com essa definição, também expunha que o território tinha um sentido de espiritualidade (legitimação da formação do Estado alemão; a intencionalidade de justificar com o que não era físico, mas que se materializava), o que podemos entender como a parte imaterial do mesmo. Ratzel (1990) pensa o território a partir da idéia, da utopia do Estado e do espírito universal (espiritualidade) e a ligação espiritual com a terra. Esse sentido imaterial do território é o que permite para Ratzel (1990) dizer que o território "ótimo", ou "solo", é aquele prédeterminado com os recursos naturais atrelados a dinâmica social para condições de sua 
projeção. Então, vemos o próprio Ratzel (1990) em seus trabalhos observar e propor a espiritualidade do território enquanto um movimento que se dá não no âmbito material, mas sim, no âmbito dos processos que se desencadeiam em virtude das relações sociais com a natureza.

Desse modo vemos uma particularidade no território em sua essência e presente também na sua etimologia, mas especialmente na sua construção histórica teóricometodológica, que é a noção disputas e imaterialidade, ou seja, o poder que está atrelado às dimensões materiais e imateriais do território e a esfera de dotar o mundo de significados através das relações sociais. O poder, de acordo com Raffestin (1993), é o elemento lógico que liga o território a ação humana dialeticamente. O poder nos revela as possibilidades materiais, contudo ele nos incita, de maneira mais provocadora, a pensar a realidade imaterial.

Raffestin (1993), o mais destacado pensador no que tange a atualidade do conceito território, em Por uma geografia do poder, fala do poder caracterizando-o com caráter multidimensional, e o que se expressa na sociedade e se materializa pelas ações. A energia (força física, braçal, trabalho vivo e manual) e a informação (trabalho abstrato, intelectual) são partes fundamentais para estabelecerem a onipresença do poder. Assim "a energia poder ser transformada em informação, portanto em saber, e a informação pode permitir a liberação de energia, portanto de força. O poder também é, nessas condições, um lugar de transmutação" (Raffestin, 1999, p. 56). O poder é inerente ao território, a sua gênese e mutação.

"O espaço é a 'prisão original' e o território é a prisão que os homens constroem para si" de Claude Raffestin (1993, p. 144). Partimos do próprio Foucault (1979), na microfísica do poder que se instaura nas relações humanas e também permeia o discurso do homem e a construção da sua representação material e imaterial no espaço. $\mathrm{O}$ espaço é a estrutura, mas também é o território, porque ele o realiza, contudo as suas diferenças estão na leitura da realidade, onde o território se faz essencial em ser lido pelo poder e o espaço geográfico não se mantém refém irresoluto desse processo.

Raffestin (1993) então procura a construção desse conceito a partir da proposição relações de poder que mobilizam dialeticamente a formação do território com base também nas relações sociais, elementos esses fundamentados nas obras de Michel Foucault, História da Sexualidade I e Microfísica do poder.

1. O poder não se adquire; é exercido a partir de inumeráveis pontos;

2. As relações de poder não estão em posição de exterioridade no que diz respeito a outros tipos de relações (econômicas, sociais, etc.), mas são imanentes a ela;

3. O poder vem de baixo; não há uma oposição binária e global entre dominador e dominados (p. 53).

No olhar desse autor sobre o conceito de território vemos as relações de poder determinando a configuração espacial, essas relações estão mediadas pelo aparato social e também pelo modelo de produção capitalista e ainda por modelos de produção que não são em essência capitalistas. "O território é o espaço político por excelência, o campo de ação dos trunfos" (Raffestin, 1993, p. 60). Esse espaço político é relacionado a imaterialidade do território, pois são o reflexo do que não se vê claramente no território material, mas que se materializa nas relações sociais e também nas relações de poder. Raffestin (1993) examina o território a partir da sua relação com o poder, onde o 
homem é inerente a essa criação, pois o território, distintamente de Ratzel (1990), se dá simultaneamente a ação humana mediada pelo poder que caracteriza e desenha o território material.

As 'imagens' territoriais revelam as relações de produção e consequentemente as relações de poder, e é decifrando-as que se chega a estrutura profunda. Do Estado ao indivíduo, passando por todas as organizações pequenas ou grandes encontram-se atores sintagmáticos que produzem o território (Raffestin, 1993, p. 152)

O território é produzido em conflito, e o conflito é fundamental para explicar o processo, nesse processo vemos as relações sociais e a luta de classes no cerne da disputa pelo território e pelo poder formador do território (Shanin, 1983). O território é o movimento incessante das disputas territoriais, das disputas nas relações de poder e a hegemonia de classes organizadas pelo capital e a contra-hegemonia de classes de resistência e/ou grupos (des)organizadas que não se satisfazem na reprodução do capital, mas comumente são cercadas e/ou cerceadas pelas mesmas. Os atores sintagmáticos são todos os atores que realizam uma ação, uma função, esse atores produzem o território e passam a então reproduzir a sua territorialização, as suas territorialidades. Os símbolos fazem parte da formação do ator sintagmático e num processo reflexo ele também forma os signos. O território então está composto dos aspectos materiais e imateriais que o determinarão.

\section{A possibilidade da leitura do território imaterial}

O território é marcado pelas relações de poder e pelas correlações de força que estão implícitas e explícitas nas relações sociais. Assim entendemos as representações simbólicas como um território que explicita leituras da realidade urbana ou agrária por meio do território material e também do imaterial. A partir das disputas territoriais inerentes ao modo de produção capitalista, que está intrínseca ao metabolismo do capital, pensamos o território imaterial não somente uma analogia ao pensamento, mas, sobretudo como a disputa do campo das idéias e conceitos, a dimensão ideológica da (re)afirmação do território material.

As representações e o capitalismo participam ativamente na construção e mais que isso, na constituição sócio-territorial da sociedade (Jameson, 1997). A imaterialidade do território não foge dessa lógica cultural do capital, e nem das iconografias de resistência dos movimentos contra essa hegemonia, por isso - Gottmann (1973), Deleuze e Guattari (1972) Haesbaert (2004a e 2004b); Porto-Gonçalves (2004); Haesbaert (2004a) e Fernandes (2009), autores que definem o território a partir de aspectos materiais, simbólicos e imateriais - entendemos também o território material e imaterial como inerentes um ao outro, numa relação vital dialética desde sua gênese até suas mutações, pois o território não existe sem a disputa das idéias, assim também, contrária, mas não contraditória, as relações se desencadeiam e se territorializam também por essa razão prática.

Portanto, para efeito didático entendemos o território material e o território imaterial, a materialidade e a imaterialidade do território, como processos distintos, porém imanentes. A materialidade (produto, resultado) e a imaterialidade (símbolos, signos) 
refletem as dimensões, e são a expressão, a impressão, os símbolos e signos do território (elementos do processo em movimento). O território material é a materialização das ações, dos desejos, dos anseios, e do contrário a isso no plano físico, isso desencadeia no processo de coisificação ou de resistência. O território imaterial é construído a partir de paradigmas que em essência são ideológicos, são interpretações da realidade a partir de distintos modelos de produção socioterritorial, e agora sim, dialeticamente se des-reterritorializando.

O território material e imaterial são e estão intrinsecamente ligados, são indissociáveis, co-existem e necessariamente se completam. A materialidade é parte essencial do território material, a imaterialidade é parte essencial do território imaterial, e ambas dependem dos seus territórios para existir. Os territórios material e imaterial são uma mesma realidade, e assim comungam. A materialização (processo) e a materialidade (resultado) acontecem cotidianamente, são razão da existência do território imaterial e vice-versa. A materialidade e a imaterialidade estão presentes no território material e imaterial, porque na sua complexidade eles nunca se separam (Fernandes, 2008b).

O território imaterial se dá no campo das ideias que tem na sua razão de existência a disputa territorial no campo das ideias, ou seja, a disputa territorial a partir de lógicas de construção de mundo. Os signos, símbolos, identidade cultural e política são a imaterialidade do território que passando pelo reforço ideológico ou capital ou da resistência ao capital, fortalecem e territorializam um e des-reterritorializa outro. Por isso a partir do território imaterial que se dá a criação das identidades culturais, pela realidade da relação sociedade-natureza que se proporciona a criação de símbolos, de sentidos ou não-sentidos (como no estranhamento de Marx). Abordamos então o território imaterial a partir de Fernandes (2009):

O território imaterial pertence ao mundo das idéias, das intencionalidades, que coordena e organiza o mundo das coisas e dos objetos: o mundo material. A importância do território imaterial está na compreensão dos diferentes tipos de território material. Nós transformamos as coisas, construímos e produzimos objetos na produção do espaço e do território. Penso o território imaterial a partir da mesma lógica do território material, como a determinação de uma relação de poder. Essa determinação deve ser compreendida como definir, significar, precisar a idéia ou pensamento, de modo a delimitar seu conteúdo e convencer os interlocutores de sua validade (p. 15).

Com essas proposições, Fernandes (2009) nos fornece os fundamentos teóricos essenciais da formação do território imaterial, além da relação dialética com a matéria, ele se provê das relações de poder e da significação (símbolos e signos). O fato que se relaciona ao convencimento também resulta na ideologia, a materialização da ideia e do desejo de torná-la real, mediado pelas relações sociais (Lukacs, 2010). Felício (2010a), vai a fundo no território imaterial e procura entender os elementos principais na sua constituição:

[...]o lugar onde se dão as disputas políticas e se desenvolvem as conflitualidades é o território material. A cada território material corresponde um território imaterial que é construído simultânea e necessariamente com o objetivo de tornar o primeiro visível ou invisível. [...] os territórios imateriais se movimentam através da luta pelo poder de dizer criando suas próprias representações e significados 
das coisas num confronto discursivo característico das sociedades capitalista através da luta de classes pelo controle e domínio do território e pelo controle e domínio dos valores culturais. (p 1-4).

O território imaterial da luta de classes e resistência é caracterizado especialmente pela cultura, e é reflexo da natureza, economia e política as quais estão inerentes signos, símbolos, tradições, identidades territoriais, entre outros que refletem a imaterialidade do seu território. É impossível que somente uma pessoa construa o território imaterial, pois ele é resultado de um arraigado processo histórico-geográfico impreterivelmente estrutural e coletivo. O território imaterial se desenha a partir da realidade das relações homem no espaço-tempo e assim ele se forma a partir da sociedade em toda sua complexidade.

Em relação à luta pela terra no Brasil, a construção espacial de relações sociais forma a decisão das pessoas que se juntam ao MST. A formação de resistência foi incorporada no entendimento particular do espaço, ou o que chamo de "espaço imaginário" - estruturas cognitivas, tanto coletivas e individuais, constituído através do vivido, das experiências, percepções e concepções do próprio espaço (Lefebvre, 1991). Analisar estes imaginários espaciais ajudará a explicar as pessoas, mais precisamente como no Brasil rural, a experiência da modernização agrícola, a abertura política, e mobilização religiosa em formas que os fez optar por deixar tudo para trás e participar de um movimento radical dos sem terra. (Wolford, 2004, p. 410).

O que Wolford (2004) nos alerta para o espaço imaginário, é o que dá margem para pensarmos o território imaterial como produto que vai além da ótica do imaginário, mas que se estabelece nas relações sociais no território e por isso no espaço geográfico. A resistência e a identidade camponesa representam a continuidade da luta e fortificação do território imaterial do campesinato, por isso se torna essencial entendermos a formação socioterritorial dos lugares, as relações sociais e de poder que estão inerentes ao território. A resistência e a recriação se tornam então as palavras-chave para entendermos a reprodução do território camponês. O território imaterial do camponês, materializados nas suas ações é que da vida a essa classe, o que faz a necessidade dela ser explicada, como Shanin (1983) nos sugeriu. O território camponês então se estabelece a favor do território que tem em seu cerne a reprodução de relações nãocapitalistas e ideologias de resistência e (re)criação.

Desse modo consideramos os seres humanos como sujeitos sociais, e por isso ideológicos e intencionais (Searle, 1995). A todo momento nos des-re-territorializamos, de maneira simultânea (Deleuze e Guattari, 1972). A movimentação dos territórios imateriais reagem de acordo com a intencionalidade de um grupo social, que podem estar embasados nas vontades individuais. Então para complementar o que Fernandes (2008a, 2008b e 2009) e Felício (2010) expõem a respeito dessa compreensão do território, temos a concepção de intencionalidade:

A intencionalidade é uma propriedade da política entendida como liberdade. As intencionalidades propõem diferentes leituras para a realidade gerando conflitualidades materializadas pelas disputas nas interpretações dos fatos. A intencionalidade como opção histórica é também uma posição política, uma preferência pelas leituras de uma determinada classe e/ou segmentos sociais (Fernandes, 2008a, p. 7). 
Vemos na intencionalidade a imaterialidade do território em movimento para a formação do território material. Eles são coexistentes e indissociáveis, o território material apresenta marcas e se desenha no espaço com base na multidimensionalidade das relações de poder, já o território imaterial é polissêmico, se dá principalmente na descontinuidade perpassando a formação da identidade cultural e o simbólico, que participam da mutação e expressão dessa formação e das relações de poder no território material.

O conceito de território então carrega no seu interior elementos como o poder, ideologia, disputa e conflito, e a intencionalidade como essa propriedade política que permeia a construção e disposição desses conceitos (Searle, 1995). A intencionalidade remete a questão da disputa de ideias na procura por legitimá-las. Desde Aristóteles, observamos o privilégio do mundo concreto e não da idéia, o materialismo, a idéia é decorrência da matéria e dos processos que a circundam. Esse foi o primeiro filósofo a falar da imaginação, sabendo que a idéia só existe na coisa, a realidade objetiva, e as causas são integradoras da matéria e i-matéria, formal e eficiente (Aristóteles, 2005).

Aqui, deixamos claro que temos o território como uma parte do espaço que está sempre em disputa. Lefébvre (1991) diz que a sociedade produz o espaço e assim o espaço é o lócus das relações sociais, que envolvem a sua produção e a sua reprodução através das formas de representação. O espaço é produto do trabalho humano em realidades físicas diversas, é o resultado da luta pela vida de indivíduos e grupos que se organizam em classes sociais para formar seus territórios. Toda relação social tem dimensões espacial e temporal, dois elementos da realidade inseparáveis. Um influencia o outro, produzindo infinitas misturas de realidades físicas e metafísicas.

Assim para que o território imaterial exista é inerente o território material como uma base, pois ele não existe por si só, mas por uma complexidade de eventos, fatos e situações que formam o território como parte do espaço e lugar de atuação do homem, onde se encontram as suas conflitualidades. Assim entendemos o território como um espaço de lutas, tanto política, econômica, social, simbólica e ideológica, por isso consideramos sua multidimensionalidade, multiescalaridade, multifuncionalidade e multiterritorialidade. Com esse suporte vemos o território imaterial como o território que pode ir além da sua materialização, que se revela na ideia e na ideologia que se expressa nas ações, na territorialização, e que é assediado constantemente pelo metabolismo societário do capital. Isso é o que torna o(s) território(s) complexo(s) e repleto(s) de contradições.

No interior do território do capital as ideologias capitalistas e no interior do território do anti-capital as ideologias de resistência ao capital estão em disputa no campo da multiterritorialidade (a sobreposição de territórios) que estão em constante atrito. Esses dois territórios especificam os territórios que conhecemos, mas não por isso eles se materializam no atrito somente entre eles mesmos. O território do capital tem na sua essência e especialmente na representação, a concorrência que se desdobra na multiterritorialidade voltada a disputa entre territórios do capital de maneira ao mais estratégico e coeso prevalecer, tendo vista também a destruição de territórios que não reproduzem o capital.

É por isso que iremos entrar nesse momento no universo do território imaterial, mas nem por isso do inexistente, ao contrário, reflete os acontecimentos territoriais e representam as disputas que acontecem na territorialização do pensamento, formando 
assim o território imaterial. Através da ficção cinematográfica será exposta uma realidade possível, aplicável ao cotidiano. É então importante que nos despojemos dos preconceitos e analisemos essa realidade como a construção de uma ideia através das disputas territoriais materiais e, sobretudo, nesse caso, imateriais.

\section{THE INCEPTION: O SONHO, A INSERÇÃO A DISPUTA ${ }^{2}$}

The Inception $^{3}$ é um conceito, e também uma técnica pensada pelo autor e diretor Christopher Nolan quando escreveu essa obra de mesmo título. Ele pensou em expor os elementos que compõem a mente humana e assim a formação da ideia. Tudo o que observou na realidade se (i)materializava na mente e no pensamento, ou seja, para ele os sonhos eram um outro território, onde poderiam acontecer disputas que determinariam a formação da ideia e determinariam os sentimentos e ações. Essa é uma ficção cinematográfica que pode nos auxiliar como analogia na compreensão do território imaterial. O território imaterial, nesse caso, que se expressam nos sonhos tem base na materialidade, nas relações sociais e de poder, tudo o que é representado tem como base uma ideia material co-determinando o real e o imaterial.

A primeira cena é o dialogo que acontece entre um senhor e um homem achado na praia. Que lugar é esse? Por que eles dialogam? Dois personagens realizam essa conversa, Sr. Saito e Sr. Cobb (Dom Cobb), e outro personagem observa tudo, Arthur. Cobb questiona e responde: "Qual é o parasita mais resistente? [...] Uma ideia, resistente e altamente contagiosa. Quando uma ideia domina o cérebro é quase impossível erradicá-la. Uma ideia que é totalmente formada e compreendida, ela permanece". Ele fala que o momento de tomá-la e moldá-la é durante o sonho quando as defesas do consciente estão mais baixas, deixando os pensamentos vulneráveis ao roubo, roubo de um segredo, ou the extraction, a extração. Ou seja, o território mais vulnerável não é a matéria, mas sim a ideia e a que território ela serve de força materializadora.

Desse modo que o Cobb e seu companheiro Arthur tentam no primeiro instante roubar um segredo importante. Ele é contratado por empresa que visa a espionagem industrial, e o objetivo é roubar Sr. Saito. O segredo que querem normalmente se materializa nos sonhos como um cofre ou um segredo em lugar oculto, e assim o procuram para cumprirem a sua missão. Essa missão é baseada em construir um aparato simbólico na projeção de lugares reais na realidade imaterial através das camadas de sonhos. Essas camadas consistem na sobreposição de territórios (interações, lugares e realidades imateriais), um sonho no interior do outro. Isso consiste o primeiro sonho como a primeira projeção após adormecer, que segue o segundo sonho que é quando os personagens adormecem no interior do primeiro sonho e assim sucessivamente. A realidade é onde vivemos, é onde sabemos que estamos vivos porque questionamos a nossa vivência, e o sonho é uma analogia a complexidade da formação da ideia/pensamento.

Então após conseguir o que queriam, existem duas maneiras de sair do sonho: a sua morte no sonho que implica em acordar, e a técnica que é chamada de kick, ou chute, é o outro modo de acordar, como uma perturbação ao sonho, como uma sensação de queda, do ultimo sonho em que está vivendo para outro sonho ou a realidade. 
Ele não consegue toda a informação, recebe o kick e acorda no primeiro sonho. Era uma cilada para Sr. Saito na projeção de duas camadas de sonho, sendo que o primeiro sonho, onde estava se passava no apartamento do seu alvo, seqüestrado então ele seria obrigado a fornecer o que eles queriam. Sr. Saito está sedado e acorda após ser morto no segundo sonho, e nesse momento pensava estar na realidade. Sob a mira de uma arma pensa estar mesmo na realidade material e assim quando vai revelar o segredo cai sobre o tapete da projeção do seu apartamento, o carpete não é de lã como deveria ser, é de poliéster, o que o faz perceber que está em outro sonho. $\mathrm{O}$ arquiteto (que executa o planejamento e projeção da realidade nos sonhos) do território do sonho errou na programação dessa realidade. Um sonho no interior de outro sonho, o território no interior do território e assim a disputa pela verdade é perdida por parte do grupo de Cobb que tentou realizar a extração.

Logo após isso eles executam novamente o kick, e saem de trem onde estavam originalmente juntamente com Sr. Saito. A equipe sai e o deixa na poltrona. Cobb e os outros parceiros se vão para dar a aparência de que era somente um sonho. De fato o seu trabalho não havia dado certo e a empresa contratante o perseguiria ainda por esse deslize. Na cena seguinte Cobb vai a um hotel, gira um pião que cai sobre a mesa, e liga para seus filhos, James e Philippa, que estão nos EUA, lugar aonde não poderia estar. O pião que caiu sobre a mesa, era um totem, uma maneira de saber que está na realidade, um objeto pequeno, potencialmente pesado, que você se apega e o conhece totalmente, único e relacionável a cada um, e no caso de Cobb é um pião que quando para de rodar e cai mostra que está na realidade. O totem é chave e assim a contradição vista no território para que quando se investigue um território saiba que ele tem mais de um lado, mais de uma forma, ele é dialético, o território é também as relações sociais, o poder, e o uso do poder. Além disso, o totem pode representar outras maneiras de reproduzir o território imaterial do anti-capital, ele não precisa ser somente a investigação da contradição, pode ser também a disputa pelo conceito e pela formação da ideia.

Após isso ele precisa então ir embora, pelo insucesso de sua missão, no entanto é surpreendido por Sr. Saito na vida real. Sr. Saito já sabia de tudo, aquilo havia sido um teste para o golpe a ser realizado. O golpe seria the inception, a inserção. Entrar e transformar a origem da ideia, subverte-la a expor outros aspectos que possibilitem novas perspectivas. Algo impossível de acordo com Arthur, mas não para Cobb que ignora num primeiro instante, mas após a proposta de eliminar a acusação de assassinado dele na justiça estadunidense, surge a perspectiva de finalmente rever seus filhos, the inception volta novamente a cena.

Então Cobb questiona, "qual a complexidade da ideia que precisa ser implantada?", ele o responde: "o meu maior concorrente é um velho com péssima saúde, e em breve seu filho assumirá o controle da empresa. Preciso que ele decida desmantelar o império do pai". O convite é aceito e então começam os preparativos para a formação de uma nova equipe, ele precisaria escolher com mais cuidado. O primeiro da equipe que precisa conseguir é o architect, o arquiteto, para projetar (projetar o sonho) a realidade nos sonhos fornecendo a aparência detalhista e que possa convencer o sonhador que sofrerá com a inserção.

Dom Cobb vai a Paris - na universidade de Paris no curso de arquitetura - requerer com seu pai (professor desse curso) um dos melhores estudantes dele para ser o seu arquiteto. Ariadne é o nome indicado, uma moça que recebe então a oferta desse 
emprego, um trabalho para que ela sobrepusesse a realidade do território dos sonhos de modo a convencer quem estava sonhando de que aquilo era realidade. "Nós criamos e percebemos nosso mundo simultaneamente, e a mente faz isso tão bem que nem notamos. Isso nos permite entrar bem no meio desse processo, controlando a parte criativa. É aí que preciso de você para criar o mundo do sonho. Trazemos uma pessoa para dentro desse sonho, e ela preenche com seu subconsciente".

A realidade a ser formada a partir do território imaterial, nesse caso o sonho projetado na ideia, é possível, pois quando estamos no sonho pensamos que estamos na realidade, e de maneira sutil o território imaterial caracterizado como capitalista exerce também essa proposição. De maneira oposta o território do anti-capital ${ }^{4}$ pressupõe evidenciar que essa sutiliza produz contradições, produz segmentação social revelando o abismo que nos encontramos no mundo de hoje. E o que gera riqueza, ou tem potencialidade para isso, se torna alvo do território do capital, e assim é com o território imaterial. A ideia, a ideologia, as visões de mundo são passíveis de apropriação pois agregam valor e co-determinam as ações humanas (Konder, 2002 e Lukacs, 2010).

Quando investigamos as contribuições de Deleuze e Guattari (1972), em o Anti-édipo: capitalismo e esquizofrenia, podemos absorver nesse trabalho a importância dada a capacidade do pensamento de sofrer o processo de des-re-territorialização, ou seja, o pensamento, no nível psicossocial e ideológico, se movimenta dessa maneira também, e se territorializa como ação inerente ao território, a expansão do mesmo, ou a desterritorialização como sinônimo de transformação, mudança, rompimento a uma lógica anterior e obrigatoriamente a reterritorialização como o estabelecimento de novas proposições materiais e imateriais (adequação ou emancipação). Assim podemos pensar que se a mente pode sofrer esse processo, logo ela também é um território que faz parte de outro território, mediado nas relações sociais e de poder, coordenando a existência dialética do território material, do território imaterial e a síntese dos mesmos em uma versão integradora e co-determinante.

É assim que pretendemos expor o território, como parte da ideia, do sonho e da criação de sua realidade, os elementos e o discurso do capital que tentam nos convencer de que o que vemos e o que ele diz é a pura verdade, o território anticapitalista tenta nos convencer de que o que vemos não é somente verdade, mas existem lacunas e contradições. É nítido que nesse espetáculo cinematográfico vemos dois territórios em conflito, dois territórios do capital que através da competição imaterial um possivelmente será estrangulado.

Ariadne então sofre sua primeira experiência de sonho compartilhado, e descobre que 5 minutos da vida real equivalem a 1 hora no primeiro sonho. A mente funciona mais depressa que a realidade e extrapola nos seus acontecimentos. O sonho é um ambiente sensível, conclui Ariadne e assim percebe que essa realidade é bastante plausível, o território imaterial é mais que visual. O problema de criar o ambiente do sonho é que as projeções do subconsciente do sonhador que serão projetadas, como as pessoas e os carros começam a convergir e perceber que aquilo não é realidade. $\mathrm{O}$ que a mente faz? Ela age como uma arma de guerra que tenta a todo custo expulsar o "vírus" para manter teoricamente as suas concepções ("natureza estranha ao sonhador, elas o atacam como os glóbulos brancos combatendo uma infecção"), então é necessário criar uma confusão no subconsciente. 
Só podemos criar o território imaterial a partir da realidade vivenciada, esse é outra dica de Arthur para Ariadne. O território vivenciado reflete a realidade no território que pensamos, a ideia materializada da força as ações e se torna ideologia, nas relações, o território então por essa razão lógica passa a existir nos planos material e imaterial, onde eles são híbridos e simultâneos. A configuração da realidade depende da conjuntura do território, da sua história e geografia que remete a produção imaterial e a suas idéias, como os valores e princípios de vida se estabelecem na realidade. O segredo, conta Dom Cobb, é não criar lugares reais, apenas detalhes que lembrem a realidade, senão qualquer um pode ficar preso no sonho e não mais acordar.

Para que esse território seja caracterizado é preciso um falsificador, ou personificador que interprete (interpretação artística, atuação) a realidade através de pessoas que componham a realidade. Eames é então o próximo da lista, um falsificador. Eames concorda com Cobb que a inserção é muito complexa, então diz: "Não se trata de profundidade, precisa da versão mais simples da ideia para que ela cresça naturalmente na mente da pessoa, é uma arte muito sutil". Cobb faz a proposta: "precisamos que o herdeiro de uma grande empresa dissolva o império do pai". Eames reflete e mostra a necessidade da criação de sentimentos anti-monopolistas, mas isso está a margem de uma ideia preconcebida, então, sobretudo essa ideia deve começar pela vertente básica: nesse caso, a relação de pai e filho e a proposta de criar situações que revelem o ódio pelo pai. Cobb se despede e Eames o propõe para auxílio na composição de elementos combinados para fazer adormecer durante tempo necessário para the inception, $\mathrm{o}$ químico Yussuf.

A equipe estava formada, Dom Cobb (extrator, e nesse caso o insersor), Arthur (planejador), Ariadne (arquiteta), Eames (falsificador), Yussuf (químico) e Sr. Saito (contrante). Mas Cobb ainda escondia o seu problema pelo qual também não poderia arquitetar, a manutenção das memórias da sua esposa falecida, Mal, que se confundia com os seus sonhos, ela aparecia e poderia descaracterizar as suas projeções e assim prejudicar toda a equipe. Mal revela as contradições de um território, ela está repleta da simbologia voltada as falhas de um sistema, o discurso incompleto e oculto, as lacunas do território que não querem ser explicadas.

De volta ao plano, Arthur explica a Ariadne o conteúdo e a criação de três níveis sonhos para isso. Ela teria então que criar o paradoxo de maneira sutil para manter eles o maior tempo possível dentro do sonho, o que seria esse paradoxo? Explica Arthur, como a escada de penrose $e^{5}$ "É como um labirinto, uma repetição que ajuda a disfarçar o limite do sonho e assim dá mais tempo até o subconsciente do outro perceber o que não é real", seria então com criar labirintos para dificultar a ação das projeções do sonhador, o filho do empresário de nome Robert Fisher, ou facilitar a fuga de quem estava trabalhando no plano da inserção. Robert Fisher, esse era o nome do rapaz que seria o alvo do plano. A companhia do Sr. Saito era então a única que impedia a empresa do pai de Fisher de ter o monopólio global da energia, e ele não poderia mais competir, seria destruído pelo outro território do capital que visava o monopólio e Fisher controlaria metade do suprimento de energia do planeta, isso se não fosse pelo sucesso da inserção.

O plano então se basearia nos laços mais estreitos de Robert Fisher com o pai (Maurice Fisher) que se dava pelo seu padrinho e melhor amigo do pai de Robert, de nome Peter Browning. Essa seria a alavanca para inserir a ideia que precisavam. Browning era o braço direito de Maurice Fisher, e isso o ligava também a Robert como conselheiro. Já que o pai estava em estado terminal, Browning o pressionava para logo assumir a 
empresa através do andamento na procuração para isso. Essa ideia então deveria ser auto gerada pelo falsificador, que interpretaria no sonho Peter Browning, e posteriormente implantada no subconsciente deveria ter o valor emocional acirrado, pois a ideia objetiva de "desmantelar o império de meu pai" não o convenceria. O plano consistiria basicamente no âmbito dos sonhos: "No nível superior (ou no primeiro sonho) abordaremos a relação dele com o pai. Algo como: "não seguirei os passos do meu pai'. No nível seguinte (segundo sonho), nós instigaremos: 'irei criar algo sozinho'. E no último nível (terceiro sonho) seremos mais incisivos: 'o meu pai não quer que eu seja ele"".

Yussuf, o químico, ficaria preparado para criar um sedativo que desse suporte a três sonhos, três camadas de território imaterial. Esse sedativo teria que ser poderoso para manter os sonhos sem que desabassem, ou seja, a sincronia do kick deveria ser perfeita para que não houvesse a possibilidade de algum dos integrantes da equipe ficar preso a realidade do sonho. A quantidade de sedativo não prescrevia que a morte no sonho acordasse a pessoa na realidade, mas por esse fator as pessoas ficariam presas no sonho de Robert Fisher até o chute. E através desse sedativo, uma semana no primeiro sonho, serão seis meses no segundo sonho e no terceiro dez anos (simplificando, 10 segundos no primeiro sonho, seriam 3 minutos no segundo sonho e 60 minutos no terceiro sonho). Após alguns dias Maurice Fisher morre e Robert tem que ir a Los Angeles para o enterro, o plano está então em andamento. Eles entram no avião e sedam Robert Fisher. O vôo de Sidney a Los Angeles de Robert Fisher seria o momento adequado para transformar as horas de vôo, no mínimo de 10 horas que precisavam na inserção, para implantar a ideia.

Robert Fisher é seqüestrado no primeiro sonho, mas o que eles não contavam é com um trem atravessando o meio da cidade e um tiroteio os perseguindo na sua chegada. Ariadne diz que não o projetou, e assim descobrem que esse território imaterial é muito mais protegido do que eles pensavam. "Um extrator ensinou Fisher a defender seu subconsciente". Esse era o problema, Sr. Saito tinha sido atingido durante o tiroteio e sua morte levaria ao coma na realidade, a corrida contra o tempo começava também. $\mathrm{O}$ primeiro passo era então demonstrar a Robert um sequestro, não simples e por dinheiro, mas para uma suposta combinação do cofre de seu pai. Eames se veste de Browning e fingi ser torturado, o que força Robert a pensar na possível combinação. Ele pede que Browning venha até ele para conversarem e assim Browning o provoca a pensar coisas que pudessem ser uma possível senha ao segredo do cofre, provocações que fazem o pensar na relação com seu pai. Visto que a relação de Robert e Maurice era muito ruim, a provocação de um sentimento positivo seria a saída, uma catarse, ou reconciliação, e o plano das três camadas de sonho atrelada a elaboração de uma ideia simples de identidade ontológica do personagem Robert Fisher se desdobraria no ideal.

Entendemos que o território é criado pelo homem e pelas relações sociais que o cercam, as relações das quais ele interage e desse modo se cria as significações de mundo, os signos e os símbolos. Essas representações que são criadas de acordo com concepções e relações que permeiam o ser humano no espaço e no tempo se territorializam e configuram a sua realidade, as suas vontades e desejos, as suas ações o seu território. Cobb teve um grande problema, revelado no decorrer da ficção, em que ele e Mal (sua esposa falecida que revela-se como o seu mal na impossibilidade de projetar), buscaram tanto a profundidade dos sonhos que não perceberam o que era de fato a sua realidade. A representação foi tão forte e real, ou convincente, que quando acordaram realmente ela pensou não estar na realidade. Ela articulou para que os dois se suicidassem e 
pudessem ter "a verdadeira vida deles novamente". A jogada com a o advogado dela resultou na acusação de assassinato para ele e assim a fuga deixando os seus filhos para trás.

Além da representação das camadas, e das possibilidades e distintos elementos que caracterizam um mesmo território, ou diferentes territórios sobrepostos, ou ainda a disputa territorial, podemos observar a temporalidade e as relações que se desenvolvem na trama e nos fornecem a aparência do território e também a sua essência. A representação, o território imaterial então se tornou a sua verdade, não que ele não o seja, mas o território do capital se faz sutil a esse ponto para não percebermos que vivemos numa realidade muito mais complexa e contraditória que a que nós olhamos, pelo território aparente. A ideia é representar as relações sociais no território pela sua aparência, e não pela sua essência nas contradições implícitas. O território imaterial será então a ideia materializada na ideologia, nos desejos e vontades, nos conflitos e confusões, nos princípios e valores que se revelam ou não (dependendo da relação social e da luta de classes) no território material e vice-versa, uma reação dialética a configuração do que consideramos como real.

\section{Da ideia materializada nas ações e imaterializada no pensamento: o imaterial do território e o território imaterial}

A ideia nunca é algo consolidado, ela está sempre em movimento, necessita da criação e recriação constante. A ideia sofre com o movimento da sociedade e das disputas territoriais. Além de estar em movimento, a construção política dela é diversa e assim bombardeia a construção do território. O processo de construção do conhecimento e do território é básico na ideia, de maneira que tudo passa por ela (consciente ou inconsciente) na sua formação até a sua transformação (Arendt, 2007). Faz parte da natureza humana o processo de construção do conhecimento e consequentemente o processo de posicionamento, intencionalidade e por fim e começo a ideologia (Searle, 1995).

Hanna Arendt (2007) define a política pelas relações entre os diferentes, pela diversidade das pessoas, a política também está envolvida com religião, história e cotidiano, por isso somos a política, pois ela faz parte de nós, faz parte da natureza humana. A política é entendida aqui como liberdade ou falta dela em detrimento da livre ação dos agentes socioterritoriais que procuram/executam a dominação (2007, p. 21).

Essa autora vai abordar em uma primeira situação o que é a política de maneira filosófica, contudo a continuação disso não é entender o que é de fato essa política, mas como ela se forma e os preconceitos que estão enraizados a esse conceito. De certo modo a política é uma parte importante da constituição social atual, mas já não é totalmente pura, pois ela nasce no meio das relações sociais como forma de pensamento/ideia que se atrela a liberdade da produção e reprodução do mesmo. Então é importante que não seja confusa as relações de dominação construídas no imperialismo como política e como o todo, mas que aquela faz parte dos ideais de alguns homens que representam uma nação, e em contrapartida todos temos a política para contestar atitudes que se colocam como "política". Por isso vemos a mesma como o intencional materializado nas ações do homem e imaterializado nas suas ideias. Isso em essência não é uma relação entre dominadores e dominados, segundo Arendt (2007) isso é um 
preconceito, que deve ser superado como político "o âmbito mundial no qual os homens se apresentam sobretudo como atuantes [...]" (p.26).

A política não pertence ao homem num primeiro momento pois ela se estabelece nas relações humanas, como Arendt (2007) chama de "entre-homens". De fato a política surge no território humano, ou território das ações humanas a partir da perspectiva de "do caos absoluto ou do caos absoluto das diferenças" (p. 21). A mesma se confunde com a ideia de organizar as diversidades absolutas com uma igualdade relativa da construção socioterritorial do ser humano, e em contrapartida a isso as diferenças também relativas. Assim o território também está relacionado a política, pelas ações humanas, no entre-espaço ser a política em si. Esse agir e (i)materializar-se se desdobra no território formando-o pelas relações políticas humanas, pois "sempre que os homens se juntam, move-se o mundo entre eles, e nesse interespaço ocorrem e fazem-se todos os assuntos humanos" (p. 36), interespaço o qual podemos chamar territorializar-se. Os homens agem no mundo real e são condicionados pelo mesmo, aí vemos a codeterminação das relações dialéticas entre o homem o território, onde eles nascem e se formam juntos.

Nenhum de nós consegue viver sem a política (opção/opinião/movimento/transformação), somos seres políticos que refletem sua ideologia. A política é a ideologia aplicada a nossa realidade e transforma o ambiente em que vivemos. Por isso a ideologia é um pensamento político carregado de intencionalidade, na visão e interpretação do mundo particular e cotidiano com base na sua história e geografia, a ideologia é a política identificada. A ideologia é uma relação, ela só existe desse modo, ela abrange a ideia, está no corpo todo e assim orienta as nossas ações. Diferentemente, no interior do pensamento de Marx (Konder, 2002) tudo o que é não correspondente ao pensamento/ação do pensador é ideológico e assim o inimigo é quem limita a ideologia dominante ao discurso e as contraditoriedades a isso o contra-discurso.

O campo onde a ideologia manifesta mais explicitamente seu poder de enviesamento é, com certeza, o campo da atividade política. O sujeito da ação política é alguém que quer conhecer o quadro em que age, quer poder avaliar o que pode e o que não pode fazer, mas, ao mesmo tempo, é um sujeito que depende, em altíssimo grau, de motivações particulares - suas e de outros - para agir. (Konder, 2002, p. 248).

O ser político se manifesta em duas vertentes, no particular e no universal, e segundo o próprio Konder (2002) é isso que o torna ideológico. Cada ser humano, cada grupamento ou segmento ao intervir politicamente, ou ainda o ato de não intervir é ser ideológico e realizar uma opção. Esse autor fala que quando algumas pessoas começam a tomar conta dos meios de produção elas se convencem de que aquilo é a verdade e vão em busca de convencer as outras. A política está bem ai, na interposição dos relacionamentos e a ideologia empurra o território no sentido de tentar expandi-lo. Assim a ideologia pode desenhar-se de duas maneiras, a primeira claramente antidemocrática, de oposição ao processo, e a segunda de continuidade de adesão ao movimento a "aperfeiçoamento" da realidade (tem por característica muitas vezes a sutileza na dominação). Linhas que desenham a realidade ideológica de quem está disposto a dominar e convencer, não que essas linhas sejam o fim, mas dois meios distintos e abertos a novas composições. Em relação ao segundo ponto, Konder (2002) nos alerta. 
Assustados com as expressões mais barulhentas dos movimentos sociais, os teóricos do elitismo repetem que são favoráveis ao progresso, mas sem sacrifício a ordem; recomendam prudência e moderação; e asseguram que qualquer radicalização nas reivindicações populares igualitárias pode prejudicar os delicados mecanismos de proteção das liberdades individuais. (p. 255, grifos do autor)

Ele ainda continua dizendo que os teóricos do elitismo não suportam uma análise que contenha as dicotomias dos governadores e governados e isso embasa uma suposta paz social pela "política" - aqui também a ideologia - de quem controla os meios de produção econômica e política e reprodução social e cultural.

A neutralidade é um discurso, uma opção política e por isso ela também é a intencionalidade. A intencionalidade é o sentido, a direção que cada um toma para si como verdade e assim escolhe os seus paradigmas. A partir do momento que consumimos o espaço, criamos nele uma intencionalidade, e a intencionalidade do espaço cria e recria o ser humano, evidentemente que isso não é determinante, mas é um ponto fundamental de referência a ser considerado. Somos produzidos pela experiência vital, pelas correlações de força, pelas relações sociais e assim pelo território material, imaterial e pela imaterialidade do território que permeia o mesmo dialeticamente a sua construção e metamorfose pelos agentes socioterritoriais ${ }^{6}$.

A partir dessas definições, geograficamente a ideia toma a forma territorial e consequentemente espacial. Raffestin (1993) nos traz o território no interior do espaço que é limitado a partir do homem em relação com a sociedade configurada pelas correlações de poder. A ideia é uma interpretação direta da realidade através da sua representação, intencional e territorial. No ato de praticar e aplicar as ideias, a ideologia no território transforma também o próprio território e formam os paradigmas. Kunh (1994) fala do conceito de paradigma a partir da construção da ideologia que é resultado de um grupo de ideias, assim ele vai trazer que o paradigma como um modelo de interpretação e atuação na realidade, vemos aí o território imaterial se formando a partir do território material e vice-versa. Esse é o processo básico de formação das teorias, grupos de pensamento que têm visões de mundo semelhantes e assim influenciam a formação do território material através de blocos de ideias, concisas ou não, hegemônicas ou contra-hegemônicas que consubstanciam o território imaterial. $\mathrm{O}$ paradigma a partir de Kuhn (1994) se desdobra em hegemonia, mas interpretamos o paradigma como sendo uma (ou várias) ideia(s), uma (ou várias) visão(ões), um conjunto de ideias que constitui a sociedade nos seus diferentes paradigmas em distintas comunidades.

As ferramentas para diferenciar os paradigmas estão intimamente ligadas a composição e elementos teórico-metodológicos e conceituais que os formam. Essa diferenciação se desdobra a partir do ponto das correlações de força que pensam categoria, conceito, mundo, ideologia, teoria e política. A disputa de concepções e projetos de desenvolvimento territorial diferenciados não implicam em que exista somente um paradigma, ou que não existam, mas que os que existem são parte essencial da disputa no território.

Um exemplo disso é próprio Estado que se considera universal e por isso não se dá conta de o quanto está envolvido. Ainda pensando a respeito disso vemos que o Estado é criado pelo homem para corroborar sua dominação pelas suas ideologias. Contudo, 
todo ser humano é ideológico, mas nem todo o ser humano é objetivado na sua sanha pela dominação. "Qual é o poder do Estado político sobre a propriedade privada? É o próprio poder da propriedade privada, sai essência trazida à sua existência. E o que resta ao Estado político em oposição a essa essência? A ilusão de que é determinante, quando, de fato, é determinado" (Konder, 2002, p.32). Isso que Marx trata como ideologia, não passa de uma ilusão ideológica segundo Konder (2002), onde o mesmo procura demonstrar o potencial construtor, destruidor e, sobretudo, desconstrutor da ideologia.

Daí podemos observar duas raízes para o processo de formação ideológica, a primeira que vem de encontro aos interesses sociais, aos interesses do próprio proletariado e do campesinato enquanto classes que vivem em confronto com o capital, na criação, recriação e resistência nos e dos seus territórios. A segunda é a questão de que no processo de formação ideológica se formam lacunas sobre a ideologia dominadora do sistema e assim classes como o proletariado e o campesinato tem a missão de impor, ou pelo menos expressar, sua ideologia libertadora para construção de uma realidade distinta (Shanin, 1983).

Segundo Marx a ideologia dominadora do capitalismo, em um primeiro momento de análise, se dá quando esse modo de produção encarna o dinheiro (na sua capacidade de agilizar a troca de mercadorias e dar valores pela conjuntura, relativizando de acordo com situações político-econômicas, passa a nortear todas as relações sociais "pondo preço em todas as coisas" (Konder, 2002, p. 46)). A generalização da mercadoria e a transformação de tudo em coisas "vendáveis" passando a ser medido e traduzido em dinheiro. Explica Konder (2002), não que esse seja o sujeito universal, mas toma o papel de "equivalente universal". A sociedade capitalista gira em torno do capital e capital movimenta/dinamiza a sociedade capitalista.

Enquanto sua esfera permaneceu restrita, o dinheiro não podia produzir todos esses efeitos. Quando, porém, a sociedade capitalista o pôs no centro da sua dinâmica, ele se transformou, segundo Marx, na encarnação das "capacidades alienadas da humanidade" [...]. E passou a agravar enormemente as distorções da ideologia. (p. 37)

A ideologia do capital (chamada por Marx de Ideologia Individualista) restringe o mundo a formação de uma sociedade conjuntural, relativizada e traduzida em valores quantificados, diferentemente da ideologia contra o capital que observa o processo histórico geográfico dialético da sociedade e qualifica culturalmente os processos sociais enquanto formadores dos seres humanos no território e vice-versa (Konder, 2002). A ideologia libertadora, ou revolucionária, se preocupa em dizer que ela não contempla toda a realidade, é uma interpretação sujeita a transformação social, o que não acontece no ímpeto da ideologia do capital que se identifica como o todo e universal, mas é singular e restrita.

As ideias da classe dominante são em cada época as ideias dominantes, pois elas tem o poder material atrelado ao imaterial (o que Marx chama de espiritual), quer dizer, "a classe que dispõe dos meios da produção material também dispõe dos meios da produção espiritual" (Marx apud Konder, 2002). E assim, essa encarnação do dinheiro foi o primeiro passo para tornar o estranhamento um elemento essencial da composição da ideologia dominadora do capital que estrangula a sociedade social, formando ela asocial (Mészáros, 2007). Nesse ponto vemos os seres humanos determinados pelo 
movimento das suas ideias e as ideias determinando o movimento dos seres humanos. Cada ideologia se forma pela sua capacidade de convencimento, coesão e/ou coerção, não que os três caminhem juntos, mas sempre, pelo menos um deles existe.

Marx em seus trabalhos, em especial no Manifesto Comunista (1988), traz a ideologia como a falsa consciência que dinamiza as atividades do capital e causa o estranhamento nas relações humanas, contudo Konder (2002) abre essa discussão e nos provoca a pensar na ideologia como um processo que "é maior do que a falsa consciência, que ele não se reduz a falsa consciência, já que incorpora necessariamente em seu movimento conhecimentos verdadeiros" (p. 49). Desse modo, Konder (2002) e Lukacs (2010) não querem desconstruir tudo o que Marx escreveu a respeito desse importante conceito, mas sim trazer uma nova interpretação, menos limitada e cética a respeito da ideologia e assim trabalhá-la a partir da visão de mundo e de transformação do mundo entre as pessoas. Konder (2002) faz questão de levantar que o conceito de ideologia, desde Lênin, na interpretação de Marx, está ligado a ideologias reacionárias e progressistas, a burguesia e o proletariado, de maneiras distintas defendendo coisas divergentes. A construção de mundos diferentes estão fundamentadas nas concepções ideológicas dos agentes socioterritoriais. Isso a partir da continuidade, na aplicação de que os processos partem do evolucionismo e se encerram nele, e uma outra que parte do rompimento com qualquer ideologia ou ação que pareça natural e universal, mas sim a ideologia contestável.

O sujeito humano existe intervindo no mundo, sendo constituído pelo movimento da história e, simultaneamente, constituindo esse movimento. Mesmo quando amplos setores da população de um país ficam reduzidos a uma situação de miséria material e espiritual, mergulhados nas formas empobrecidas e limitadas do senso comum, não se deve perder de vista o fato de que eles continuam a ser integrados por sujeitos humanos. (p. 109).

Os movimentos da sociedade (formação social) que constituem o homem e o território são multidimensionais, multiescalares e recíprocos, pois eles se co-determinam nas suas relações. A formação da ideologia depende também dessa composição e é preciso lembrar que mesmo elas limitadas ou empobrecidas ainda estão mergulhadas no meio humano. Não podemos ignorar a capacidade cultural da criação e recriação do território pela força do pensamento que se traduz nas ações, e um autor como Gramsci, materialista, sempre esteve atento para importância da criatividade humana no seu poder inovador, "as supra-estruturas em torno dos valores históricos do conhecimento da cultura" (Konder, 2002, p. 107).

A partir disso lemos Antônio Gramsci (2001), pensador italiano e um dos fundadores do Partido Comunista na Itália, revelar outras concepções a respeito do conceito de ideologia e mostrou ser necessário um olhar profundo para as diferenças internas do mesmo. Pois a ideologia não poderia ser simplesmente limitada e levada a "pura estupidez ou a sua inutilidade", era preciso entendê-la a partir da capacidade que tem de transformação ou manutenção. Gramsci dizia que era preciso diferenciar ideologia orgânicas que são necessárias a uma estrutura, e outras que são ideologias arbitrárias ou racionalizadas, e essas fazem parte do desejo humano (Konder, 2002).

Vemos nos trabalhos de Gramsci a compreensão do território através da matéria (estrutura) e idéia (superestrutura) - dialética (Saquet, 2010). Gramsci (Konder, 2002) 
ressalta ainda em seu trabalho a imanência das relações ideológicas ao consubstanciamento da matéria (território), uma relação recíproca entre a estrutura e a superestrutura. "Para Gramsci, estrutura e supra-estrutura formam um bloco histórico, uma unidade contraditória e complexa determinada historicamente." (Saquet, 2004, p. 142). Ainda com base nesse trabalho, Saquet (2004) vai abordar a inerência da ideologia no que tange a formação e mutação na economia, política e na unidade intelectual e moral, que de certo modo pode legitimar a hegemonia de um grupo social sobre outro. Aí Gramsci (2001) vai falar com base na sua vivência, no período de governo militar italiano, onde o mesmo era perseguido com base numa ideologia (território imaterial) fortemente instaurada que se aplicava a arbitrariedade do conceito e não uma ideologia transformadora, a qual pretendia demonstrar em seus escritos (Konder, 2002). A ideologia se firma na sua capacidade de sustentação que está no estabelecer das razões que se identifica com um grupo.

Além de Gramsci (2001) expor que um dos principais equívocos a respeito da ideologia é tratá-la ideologicamente, Konder (2002) relata o que esse autor pensa a respeito do que seria a ideologia: "Ele diz que a ideologia se torna ciência quando assume a forma de 'hipótese científica de caráter educativo energético' e é 'verificada (criticada) pelo desenvolvimento real da história"'. Ou seja, a ideologia age também como força que cria uma hipótese científica e reflete essa mutação juntamente com teoria e trabalhos empíricos, formando um paradigma que se estabelece como um desafio a realidade pelos trabalhos científicos que buscam a objetivação dos problemas em soluções. A ideologia ao mesmo tempo que se torna um movimento que da forma (a sua forma) à realidade através das ações verificado no desenvolvimento real da história, e aí, acrescentamos, geografia, também se cristaliza em território material e imaterial.

Todo elemento (político, ideológico, econômico, social e cultural) que se expressa no território com materialidade e comprova assim o território material na sua existência, não é senão um vetor de ida e volta do seu conteúdo imaterial, cognitivo, artístico ou signo/simbólico. De maneira que o território material se expressa no território imaterial numa relação de transformações mútuas e co-determinação pelos sujeitos que comprovam a sua veracidade. É nas relações sociais no território material que observamos a dica de que existe o território imaterial, por essa capacidade, e antes disso potencialidade de representar a ideia no plano do território/pensamento, como um signo mediado pelas correlações de força e vivência social e um símbolo determinado arbitrariamente pelas regras sociais.

\section{TERRITÓRIO E JUST DO IT}

O território imaterial então é constituído do conjunto de relações sociais, das modalidades de produção, reprodução, conhecimento e de aquisição de informações que, sedimentando-as na força de trabalho e na ação humana, são em seguida ativadas e vislumbradas no processo material e de recriação do território material (Gorz, 2005). André Gorz (2005) em seu trabalho sobre $O$ imaterial nos elucida importantes elementos da constituição da imaterialidade, do trabalho material ao trabalho imaterial, das relações de composição do capital social e do capital do conhecimento, ambos imateriais, mas que tem embasamento e viés na materialidade das ações no território, incluindo assim disputas, conflitos e intencionalidade na transformação dessas ideias em matéria. 
Um dos exemplos mais claros ilustrados por André Gorz (2005) e David Harvey (2006) que podem nos auxiliar na compreensão do território imaterial e de como ele se relaciona com o território material na sua multidimensionalidade, multiescalaridade e multifuncionalidade é a Nike. A Nike é uma empresa conhecida mundialmente, fabricante de material esportivo com destaque para o setor calçadista. Ela se faz representante política e econômica quando se coloca como representante estadunidense enquanto marca oficial, e sobretudo cultural quando atrela ao esporte e ao Just do it (simplesmente faça) como a mensagem de que o esporte é simples em ser realizado, ele só necessita da vontade de cada um para isso.

Cada organização procura reforçar sua posição obtendo trunfos suplementares, de tal modo que possa pesar mais que outras na competição: 'o poder (político) aparece, em conseqüência, como um produto da competição e como um meio de contê-la'. Obter trunfos suplementares não significa de modo algum possuí-los ou dominá-los. (RAFFESTIN, 1993, p. 59)

Ela ultrapassa os limites de escala e se territorializa na mente das pessoas do mundo como sonhos, na propaganda e o marketing cristalizam o seu território (ela deixa sua marca na aparência do território) (Deleuze e Guattari, 1972). Outro ponto é que a "Nike não possui nem instalações, nem máquinas: sua atividade se limita à concepção e o design" (p. 39). A fabricação, o marketing e distribuição são terceirizados e assim não se instalam de fato nos EUA. O território imaterial da Nike é grande e forte, pois ela atrela o poder da pressão dos contratos, a imaterialidade do capital intelectual, o fetichismo do consumo, e a venda de sonhos que podem se tornar realidade, e junto isso a pessoas $\left(\operatorname{atletas}^{7}\right)$ de preferência que vendem a sua imagem para o mundo inteiro.

O território imaterial dela é muito maior que o seu território material, pois essa empresa já não se preocupa com simplesmente reduzir o tempo de produção e aumentar o lucro, eliminando estoque e trabalho ocioso, mas sim, ela garante contratos (forçando e estreitando ganhos desses parceiros na reavaliação permanente dos contratos) com parceiros que intensificam a exploração de sua mão-de-obra (Harvey, 2006). A Indonésia e o Vietnã são apenas dois países, dos muitos, que ratificam o território do capital, no caso das empresas do capital (incluímos aqui a Nike). Harvey (2006) vai falar dos subcontratos feitos por essas empresas com fábricas em outros países, considerados periféricos, e esses subcontratantes tendem a pagar baixos salários e impor gerência brutal. Esse é o território que não aparece, e assim que o território imaterial do capital se estabelece fortemente, pois essas lacunas não são explicadas, elas não ficam expostas, e quando ficam, são mascaradas. Em seguida um depoimento de um trabalhador na fábrica contratada pela Nike.

[O Senhor Nguyen] descobriu que o tratamento dos trabalhadores pelos gerentes de fábrica no Vietnã (de modo geral coreanos e taiwaneses) é uma "fonte constante de humilhação", que recorrem a maus-tratos verbais e assédio sexual com frequência e que "é comum o uso de punições corporais". Ele descobriu que quantidades extremas de horas extras obrigatórias são impostas aos trabalhadores vietnamitas. [...] Em vez de acabar com as condições abusivas nas fábricas, a Nike recorreu a uma elaborada campanha internacional de relações públicas para fazer parecer que se importa com seus trabalhadores. (Herbert apud Harvey, 2006). 
E na continuidade dessa exposição, Harvey (2006) posiciona a necessidade muito além de campanhas e discurso mascarado para transformar a realidade. Ainda no decorrer do trabalho de Harvey (2006), ele vai apresentar a essência podre do território capitalista através de falas de trabalhadores (sub)contratados por fábricas que tem esse acordo com a Nike, a Reebok e a Lévi-Strauss. São bárbaras declarações de condições físicas e psicológicas precarizadas no território, que vão desde os baixíssimos salários, a superexploração do trabalhador, a falta de estrutura até a insalubridade e a humilhação pela opressão física e mental (Harvey, 2006).

Desse modo, essas empresas (o grande capital representado na ideia, no desejo e na ação) compram a preços muito baixos os produtos entregues pelos contratados e revende com sua marca. Ou seja, o trabalho e capital fixo que se dá no território material, na estrutura da fábrica, são frequentemente desvalorizados, já o território imaterial permeado por essa capital imaterial atrelado as ideias e a publicidade é avaliado na Bolsa de Nova Iorque, por exemplo, com ganhos imensuráveis (Gorz, 2005 e Harvey, 2006).

Assim Gorz (2005) nos ajuda a pensar o quão é real o território imaterial, como ele pode se desenhar no caso desse território imaterial pró-capital incluindo apropriação, exploração e ganho social e cultural. A base material, nesse exemplo, é muito menor que a base imaterial, se tratando da matriz, comparada a essa base imaterial em todas as proporções territoriais.

E como em uma batalha, o território imaterial é disputado por outras empresas que na maioria das vezes sofrem com a força imaterial e material (nessa caso pelo poder de pressionar através de dumping e/ou holding). A expansão do território (dinâmica de ideologia-pensamentos-sonhos) dessa transnacional estadunidense é visualizada no imaterial e no material e derradeiramente esmaga outras companhias. Isso nos revela também outra característica já presente no território, além da sobreposição de territórios: a descontinuidade do mesmo no campo material e, sobretudo no campo imaterial, a descontinuidade na continuidade. Isso se desdobra em entendermos também a incontrolabilidade do território capitalista em "abocanhar" outros territórios capitalistas.

Território descontínuo na sua continuidade que se propõe também a assegurar conceitos, e é isso que acontece nos territórios do capital e do anti-capital que disputam e se propagam ou retraem. O que não elimina o território anterior ao capital, ele o existia enquanto território em disputa, contudo o acirramento das disputas territoriais nas relações sociais acontece no modo de produção capitalista e na necessidade de explicar esses processos contraditórios e divergentes.

Essa é parte complicada e que deve ter maior atenção dos grupos (pessoas com o mesmo intuito que podem ser também uma classe) que constroem e pretendem expandir seus territórios. "A monopolização de um conhecimento, de uma competência, de um conceito, continua, no entanto, uma tarefa difícil. Ela exige um investimento financeiro frequentemente muito superior àquele que demandou a produção do conhecimento que lhe serve de base" (Gorz, 2005, p. 45). É nítido que nessa passagem ele está falando da preocupação dos conceitos criados no território do capital, mas essa proposição serve também para entendermos a dificuldade de criar e modelar um conceito no território imaterial do anti-capital. Como no exemplo da Nike, o conceito de excelência em material esportivo; ou ainda pensando no contexto de trabalho anteriores relacionados a geografia agrária, com os conceitos campesinato e agricultura familiar (Fernandes, 
2009, Cubas, 2009 e Felício, 2010a e 2010b). A Nike pode ser visualizada como exemplo real do the inception, o território construído através do discurso e da representação de uma ideia que se torna um estilo de vida, o que está por trás disso é o que devemos prestar atenção para não ficarmos no interior do sonho.

O investimento aí citado pode ser o financeiro, mas pode não ser exclusivamente ou principalmente esse, porque o investimento para se tornar um conceito válido é o respaldo midiático ou da própria academia cientifica, ou de ambos. Então o que diverge é o porquê esses conceitos são legitimados e quem está por trás desse respaldo, uns para dominar (incorporar e/ou destruir) e manter a expansão de um território, outros para mostrar uma realidade difusa, com lacunas e cheia de mazelas, com novas proposições e configurações que se desdobram nos processos sociais, nas relações de poder e no desenvolvimento territorial.

Em síntese, sobre os processos que se mostram inerentes a Nike, vemos a sua materialidade manifestada na mercadoria, na criação do consumo, nas várias empresas preocupadas em criar a necessidade, especializadas no design e marketing que recaem sobre a imaterialidade do Just do it, da ficção cultural de fazer parte dessa realidade. $\mathrm{O}$ seu território material se expressa na complexidade das relações sociais e de poder que estão incluídas no espaço, temos no material o aparato físico, os prédios administrativos, centros de tecnologia, fábricas terceirizadas. O território imaterial (aparente) pretendido por essa empresa está na representação coesa da sua realidade, na qualidade dos produtos e das mercadorias, já o território imaterial em essência se revela nas suas profundas contradições, o discurso não explica tudo (e essa é a intenção), alias ele não explica quase nada, não explica a rigidez de contratos firmados em breves períodos de tempo e forçam a super-exploração da mão-de-obra e resultam na homogeinização da cultura, um território singular e particular com aparência de universal e comum.

\section{CONSIDERAÇÕES FINAIS}

A disputa conceitual, de significados, a criação de identidade, a resistência, os aparatos políticos, econômicos, sociais, ideológicos, culturais, são elementos e razão de coexistência para o território mediado nas diversas relações de poder. É preciso então nos amparar dessas proposições, desde o The Inception, como uma abordagem territorial que representa, com os devidos limites, a realidade material e imaterial, até a formação da ideia legitimada na ideologia, e o caso exemplo da Nike. O território se faz então nas relações sociais e de poder, ele se materializa e se imaterializa também por esses elementos, ele reage dialeticamente com a presença ideológica humana, a intencionalidade, seus desejos e vontades que se expressam e configuram o espaço.

O território do capital se situa em aparentar a realidade como discurso único, e essa é a sua essência, a razão de não se explicar por completo, e assim ele se torna forte. Esse território é legitimado então quando o que está posto é a resolução para todas as coisas. Ao contrário disso, a essência do território anticapitalista é desenhada nas ações de resistência e (re)criação, em explicitar a contradição, as mazelas e a marginalização no território. A imagem (aparência) não pode ser atribuída a totalidade, ela apenas faz parte de uma realidade muito mais complexa do que vemos, o invisível (ou aquilo que ainda 
não foi escancarado) é o desafio do território imaterial do anti-capital. E assim o nosso desafio.

\section{BIBLIOGRAFIA}

ARENDT, H. O que é política? Rio de Janeiro: Bertrand Brasil, 2007.

ARISTOTELES. Categorias. Goiânia. Editora UFG: Alternativa, 2005.

CHAYANOV, A. V. Teoria dos sistemas econômicos não capitalistas. In: Graziano da Silva, J \& Stolcke. A Questão Agrária. SP: Brasiliense, 1981.

CUBAS, T. Estudo da Contribuição da Imprensa na Representação dos Camponeses e Ruralistas no Pontal do Paranapanema de 1998 a 2008. Monografia (Bacharelado em Geografia) - Departamento de Geografia da FCT-Unesp. Presidente Prudente, SP, 2009.

CUBAS, T. “Eu apoio o MST”. Presidente Prudente: Boletim DATALUTA (outubro), 2010.

DELEUZE, G. e GUATTARI, F. O anti-édipo: capitalismo e esquizofrenia. São Paulo: Assírio e Alvim. 1972.

FELÍCIO, M. J. O território imaterial do campesinato. Campo-Território: revista de geografia agrária, v. 5, n. 9, p. 18-32, fev., 2010a.

FELICIO, M. J. Camponeses/Agricultores Familiares: Paradigmas em questão. Tese (Doutorado em Geografia) Faculdade de Ciências e Tecnologia da Universidade Estadual Paulista. Presidente Prudente, 2010b.

FERNANDES, B. M. A formação do MST. Petrópolis: Editora Vozes, 2000.

FERNANDES, B. M. Questão Agrária: conflitualidade e desenvolvimento territorial. In: BUAINAIN, A. M. (org). Luta pela terra, reforma agrária e gestão de conflitos no Brasil. P.173-230. Campinas: Editora da Unicamp. 2008a.

FERNANDES, B. M. Entrando nos territórios do território. Presidente Prudente: Boletim DATALUTA (março), 2008b.

FERNANDES, B. M. Sobre a tipologia de territórios. In: SAQUET, A. M. e SPOSITO, E. S. (org). Territórios e territorialidades: teorias, processos e conflitos, p. 197-215. São Paulo: Expressão Popular, 2009.

FERNANDES, B. M. A ocupação como forma de acesso à terra. Artigo apresentado no XXIII Congresso Internacional de da associação de Estudos Latino Americanos. Washington-DC, de 06 a 08 de Setembro de 2001.

FOUCAULT, M. A microfísica do poder. Rio de Janeiro: Editora Graal. 1979. 
FOUCAULT, M. A história da sexualidade I: a vontade de saber. Tradução de Maria Thereza da Costa Albuquerque e J. A. Guilhon Albuquerque. Rio de Janeiro: Editora Graal. 1988.

GRAMSCI, A. Cadernos do cárcere. Tradução de Carlos Coutinho, Luiz Henriques, Marco Nogueira. Rio de Janeiro: Civilização Brasileira, 2001.

GORZ, A. O imaterial: conhecimento, valor e capital. São Paulo: Annablumme, 2005.

GOTTMAN, J. The significancy of territory. Charlottesville: The University Press of Virginia, 1973.

HAESBAERT, R. O mito da desterritorialização: do "fim dos territórios" à multiterritorialidade. Rio de Janeiro: Bertrand Brasil, 2004a.

HAESBAERT, R. Des-caminhos e perspectivas do território. In: RIBAS, A., SAQUET, A. M. e SPOSITO e E. S. (org). Territórios e Desenvolvimento: diferentes abordagens. Francisco Beltrão: Unioeste. 2004b.

HARVEY, D. Espaços de esperança. 2a Ed. São Paulo: Editora Loyola, 2006.

JAMESON, F. Pós-modernismo: a lógica cultural do capitalismo tardio. Tradução Maria Elisa Cevasco. São Paulo: Ática. 1996.

KONDER, L. A questão da ideologia. São Paulo: Companhia das Letras, 2002.

KUHN, T. S. A estrutura das revoluções científicas. São Paulo: Perspectiva, 1994.

LEFEBVRE, H. The Production of Space. New York: Oxford University Press, 1991.

LEFEBVRE, H. Lógica Formal. Lógica Dialética. Rio de Janeiro: Civilização Brasileira, 1979.

LUKACS, G. Prolegômenos para ontologia do ser social. São Paulo: Boitempo, 2010.

MARTINS, J. S. Os camponeses e a política no Brasil. Petrópolis: 1981.

MARX, K. Manifesto do Partido Comunista. São Paulo: Global. 1988.

PORTO-GONÇALVES, C. W. Geografia da riqueza, fome e meio ambiente: pequena contribuição crítica ao atual modelo agrário/agrícola de uso dos recursos naturais. In: OLIVEIRA, A. U. e MARQUES, M. I. M. (org.). O campo no século XXI: território de vida, de luta e de construção da justiça social. São Paulo: Casa amarela; Paz e Terra, 2004. p. 27-64.

RAFFESTIN, C. Por uma geografia do poder. São Paulo: Ática, 1993.

RATZEL, F. Geografia do homem (Antropogeografia). In: MORAES, Antonio Carlos. Ratzel. SP: Ática, 1990. 
SAQUET, M. A. O território: diferentes interpretações na literatura italiana. In: RIBAS, Alexandre; SAQUET, Aurélio Marcos; SPOSITO e Eliseu Savério (org). Territórios e Desenvolvimento: diferentes abordagens. Francisco Beltrão: Unioeste. 2004.

SANTOS, M. Metamorfoses do espaço habitado, fundamentos teórico e metodológico da geografia. Hucitec: São Paulo, 1988.

SEARLE, J. Intencionalidade. São Paulo: Martins Fontes, 1995.

SHANIN, T. La Classe Incomoda: Sociología política del campesinato en una sociedad em desarrollo (Rússia 1910-1925). Vérsion Española de Fernando Andrada Tápia. Madri: Alianza Editorial 1983.

WOLFORD, W. This Land is Ours Now: A New Perspective on Social Movement Formation, Annals of the Association of American Geographers, 2004, p. 409-424.

\title{
NOTAS
}

\begin{abstract}
${ }^{1} \mathrm{O}$ espaço é a razão geográfica, pois ele é a categoria de análise fundamental para essa ciência. O espaço se adequa as proposições da Geografia Crítica que se preocupa com a expressão e impressão das relações no mesmo, essas relações que se desdobram numa configuração espacial em diferentes temporalidades do tempo lento e o tempo rápido, das rugosidades (SANTOS, 1988).
\end{abstract}

${ }^{2} \mathrm{O}$ texto escrito tem base na produção cinematográfica, The Inception, com interpretações próprias. A narrativa dessa produção foi reproduzida fielmente em alguns momentos e indiretamente em outros com o intuito de exemplificar a configuração e o debate do território material e imaterial.

${ }^{3}$ Filme escrito e dirigido por Christopher Nolan que tem o seu título original em inglês (EUA) The Inception e traduzido para o português como $A$ origem. Filme produzido pela Warner $\operatorname{Bros}{ }^{\circledR}$ e a Legendary Pictures®.

${ }^{4} \mathrm{O}$ anti-capital (coesão conceitual de negação e resistência), não é ausência do capital ou do sistema capitalista, pois isso é impossível, mas é a resistência, recriação e/ou retaliação a essa lógica, um território baseado em essência em outros elementos de reprodução, relações não capitalistas de (re)produção. Esse território do anti-capital é o território comandado por relações sociais distintas das que se desenvolvem no território do capital, relações que desenvolvem a auto-exploração, coletividade e igualdade, não a (super)exploração, mais-valia, individualismo e segmentação social (LEFEBVRE, 1979 e 1991; MARTINS, 1981; FERNANDES, 2001 e 2009). O território imaterial que propõe o anti-capital é o que reproduz relações não-capitalistas (CUBAS, 2009 e 2010). O capital ignora as relações não-capitalistas em sua análise (e procura englobá-las num discurso único), e se destaca então em apropriar tudo e todos, já o anti-capital não ignora, mas procura questionar as suas incoerências (FELÍCIO, 2010a).

${ }^{5}$ A escada de Penrose é um objeto impossível criado por Lionel Penrose. Pode ser visto como uma variação do triângulo de Penrose. Ela representa um objeto que mistura o impossível com a realidade. Veja em: http://www.educ.fc.ul.pt/docentes/opombo/seminario/escher/escher3.html.

${ }^{6}$ Quatro classes sociais apontadas por Chayanov (1981) e Shanin (1983): burguesia (capitalistas), proprietários de terra, proletariado e campesinato. 
${ }^{7}$ Do futebol: Ronaldo Nazário, Cristiano Ronaldo e Wayne Rooney. Do tennis: Roger Federer e Rafael Nadal. Do basquete: Michael Jordan, Lebron James e Kobe Bryant. 